\title{
Vadeli Pamuk Emtiasinda Kontrat Pozisyonlarının ve Pamuk Reel Piyasa Dinamiklerinin Vadeli Pamuk Emtiası Getirisi Üzerine Etkileri
}

\section{Orhan ÖZAYDIN'}

Makale Gönderim Tarihi: 02.10.2019

Makale Kabul Tarihi: 16.03.2020

\section{Öz}

Emtia vadeli ișlem piyasaları hem koruma hem de portföy çeșitlemesi sağladığı için yakın tarihimizde piyasa katılımcılarının ciddi ilgi kaynağı olmuștur. Fakat bu ilginin büyüklüğü, spekülatif hareketlerin fiyatlara etkisinin olabileceği endișesini doğurmuștur. Bu çalıșmada, 2009-2018 yılları arası vadeli pamuk emtiası getirilerinin, spekülatörlerin ellerinde tuttuğu uzun ve kısa kontrat pozisyonları ve piyasanın reel üretim, tüketim, stok gibi miktar verileri ile nasıl etkilendiği anlașılmaya çalıșılmıștır. Koșullu değișen varyans modeli $\operatorname{EGARCH}(1,1)$ kullanılarak olușturulan ortalama ve varyans denkleminde, spekülatörlerin pozisyonlarının ve stok/kullanım oranlarının getiri ile etkileșimde olduğu görülmüștür. Reel piyasa miktar verisi stok/kullanım oranının, kontrat pozisyon verisi spekülatör pozisyonlarından getiri üzerinde daha etkin olduğu anlașılmıștır.

Anahtar Kelimeler: Vadeli İșlemler, Emtia Piyasaları, Türev Piyasa Katılımcıları, Arz ve Talep.

Jel Kodları: G13, Q02, Q1 1

Dr. Öğr. Üyesi, İstanbul Gelișim Üniversitesi, Uluslararası İșletmecilik ve Ticaret, oozaydin@ gelisim.edu.tr, Orcid ID: 0000-0003-2585-1437 


\section{Cotton Commodity Futures Contract Positions and Real Cotton Commodity Market Dynamics Effects on Cotton Futures Returns}

\section{Abstract}

Commodity futures have been a major source of interest for market participants in recent history. However, the magnitude of this interest has raised the concern that speculative movements may have an impact on prices. it is tried to understand how cotton commodity returns between 2009-2018 are affected by long and short contract positions held by speculators and real market data such as production, consumption and stock. By help of $\operatorname{EGARCH}(1,1)$ model, it was seen that the position of speculators and the stock/usage ratios interacted with the return. The stock/use ratio, was found to be more effective on yield than speculator positions.

Keywords: Futures, Commodity Markets, Derivative Market Participants, Supply and Demand.

Jel-Classification: G13, Q02, Q1 1

\section{Giris}

Vadeli ișlem piyasalarının iki önemli fonksiyonu risk transferi ve spot (nakit) fiyatların keșfidir. Vadeli ișlem piyasalarının risk transferi fonksiyonunun ișlevi, korumacıların karșısında riski transfer edebilecekleri piyasa katılımcıları bulmaları ile sağlanır. Bu yöntem tarihte çok eskilere dayansa da yakın geçmișimizde teknoloji ve küreselleșme sonucunda daha da yayg ınlașmıștır. Portföy çeșitleme aracı olması ve fayda sağlaması adına son yıllarda vadeli ișlem piyasaları yatırımcıların dikkatini çekmiștir. 2008 krizi ile birlikte spekülatörlerin vadeli ișlem piyasalarındaki varlıkları sorgulanır hale gelmiștir. ABD Vadeli Emtia Ticaret Komisyonu'na (CFTC: Commodity Futures Trading Commission) kayıtlı vadeli ișlem aracı kurulușlarının (FCM: Futures Commission Merchant) müstteri hesaplarındaki yirmi yıllık gelișmeye bakıldığında ilginin büyüklüğü anlașılmaktadır; 2002 yılında 64.3 milyar USD olan vadeli ișlem fonları devamlı artıșını sürdürmüș ve 2002 yılına göre 2018 yılında \%354 artıșla 291.8 milyar dolar gerçekleșmiștir (CFTC, Agency Financial Report, 2018).

Masters, beklenmedik spekülatif alımların baskısı vadeli emtia fiyatlarında balona sebebiyet vermekte ve bunun da spot fiyatları arttır- 
masına neden olmakta tezini savunmuștur (Masters \& White, 2008). Literatür genelinde yapılan birçok araștırmada, spekülatörlerin emtia piyasalarında istikrarı bozucu aktivitelerinin genelde olmadığı anlașılsa da (Irwin \& Sanders, 2012a) emtia ve dönem özelinde spekülatif baskıların fiyat üzerindeki etkileri de görülmüștür. Literatürden verilecek birkaç örneğe bakıldığında, James (2015) bakır ve petrol; Irwin (2012b) soya, mısır ve buğday; Brunetti ve diğerleri (2011) petrol ve doğalgaz gibi emtia üzerinde yaptığı çalıșmalarda spekülatif aktivitelerin fiyat ile ilișkisinin bulunmadığını söylemiștir. Bununla birlikte, Daley (2013) petrol; Manera ve diğerleri (2013) soya ve mısır; Guilleminot ve diğerleri (2013) ve Apperson (2017) pamuk emtiasında spekülatif hareketlerin fiyat ile ilișkisini ortaya koymușlardır. Bunun yanında, fiyatlara etken olan temel reel miktar arz-talep teorisine göre, reel miktarsal talebin (tüketimin) artması fiyatları arttıracağı, reel miktarsal arzın (üretimin) artması fiyatları azaltacağı ve emtiaya özel olarak stokların artması (düșük talep yüksek arz) sebebiyle fiyatları azaltacağı yönündedir. Literatürden örneklere bakıldığında; Macdonald (2009), ABD arz ve talep dinamiklerinin ABD arazi pamuk fiyatını etkilediği; Chua ve Tomek (2010), mısır emtiasında beklenen üretim vadeli fiyatları düșürdüğünü; James (2015), 2002 ile 2008 arasında petrol ve bakır emtiasında talebin fiyatı etkilediği; Janzen (2013) pamuk emtiasında stokların fiyatları etkilediğini söylemișlerdir.

Bu çalıșmada daha önce literatürde fazla yer bulmamıș pamuk emtiası özelinde inceleme yapılmıștır. Son 10 yılın ortalamasına göre yıllık 6.4 milyon ton üretim ile Çin dünyada birinci sıradadır ve 720.000 ton üretim ile Türkiye dünya pamuk üretiminde bașı çeken ilk 7 ülkeden biridir. 2018 CFTC Agency Raporuna göre pamuğun da içinde olduğu tarım emtia ticaret hacmi, toplam vadeli ișlemler (FX, faiz, enerji, metal, tarım) hacminin \%9'unu olușturmaktadır. Aynı yıl için vadeli pamuk emtiasının açık pozisyonları ise tarım emtiaları içinde $\% 5$ 'in altındadır (CFTC, 2018a). Hem literatür çerçevesinde hem de raporlar ıșığında, vadeli pamuk emtiası piyasasının diğer emtia piyasalarına göre daha az ișlem görmesinin sonucunda, spekülatif katılımcıların vadeli kontrat "pozisyonlarının" ve "reel dinamik" verilerinin -üretim, tüketim, stok- getiri ile etkileșimde olabileceği düșünülmektedir. Bu iki olgunun getiri üzerindeki etkisinin aynı modelde incelendiği bir çalıșmaya geçmiș literatürde rastlanmamıștır. Bu veri setlerinin ayrı ayrı getiri ile etkileșiminin olup olmadığı anlașılabileceği gibi bunun yanında bu iki veri setinden hangisinin getiri üzerinde daha baskın olduğu da incelenmiș olacaktır. 2009-2018 
yılları arası aylık verilerin kullanıldığı çalıșmada, vadeli pamuk emtiası getirisi bağımlı değișken olarak, pozisyon ve reel dinamik verileri bağımsız değișken olarak ele alınmıștır. Getiri verisi ile olușturulan EKK modelinde ARCH LM etkisi olması sebebiyle koșullu değișen varyans modelleri arasından koșulları sağlayan model $\operatorname{EGARCH}(1,1)$ modeli kurulmuștur. Tüm değișkenlerin tek modelde toplandığı $\operatorname{EGARCH}(1,1)$ modelinin ortalama denkleminde, spekülatörlerin hem kısa hem uzun pozisyonları anlamlı sonuçlar vermiștir. Aylık spekülatif uzun net pozisyon değișimlerinin aylık getiri ile pozitif, aylık spekülatif kısa pozisyon değișimlerinin aylık getiri ile negatif ilișkili olduğu görülmüștür. Yine ortalama denklemde, Çin dıșı ülkeler stok/kullanım oranı ve Çin stok/ kullanım oranı istatistiki anlamlı sonuçlar vermiștir. Her iki stok/kullanım oranlarının getiri ile negatif ilișkide olduğu görülmüștür. Pozisyon ve reel dinamik verilerinin getirinin üzerindeki etkilerini karșılaștırdığımızda ise, stok/kullanım verilerinin, spekülatif pozisyonlarının değișimlerine göre getiri üzerinde daha büyük etkiye sahip olduğu anlașılmıștır. Modelin varyans denklemine bakıldığında, geçmiș varyansın ve hata terimlerinin karelerinin getiri oynaklığını etkilediği görülmüștür. Ayrıca verilere uygulanan Granger nedensellik analizine göre getirinin, ithalat, Çin stok/ kullanım oranı ve Çin dıșı tüketim verilerinin Granger nedeni olduğu sonuçları görülmüștür.

Çalıșmanın ikinci bölümünde vadeli ișlem fiyatları ile ilgili teori ve devamında fiyatları etkilediği düșünülen pozisyon ve reel dinamik verileri hakkında yapılan literatür çalıșmaları bulunmaktadır. Üçüncü bölümde veri ve ekonometrik yöntem anlatılmıș, dördüncü bölümde ekonometrik bulgular gösterilmiștir. Sonuç bölümünde ayrıca öneriler paylașılmıștır.

\section{Teori ve Literatür}

Piyasa katılımcılarının ve reel dinamik verilerinin vadeli emtia getirileri ile etkileșimde olduğu geçmiș literatürlerde ele alınmıștır. Yapılan taramalarda bu ayrı iki unsur, münferiden bağımsız değișkenler olarak getiri verisiyle ilișkilendirilmiștir. Bu sebeple yapılan literatür çalıșmaları her iki olgu için ayrı bașlıklarda anlatılmıștır. Bu çalıșmada, bu iki veri seti tek modelde birleștirmiștir.

\subsection{Piyasa Katılımcılarının Pozisyonlarının Vadeli Emtia Getirileriyle Etkileșimi}

Bir piyasada fiyatlar temel olarak arz ve talep kanunları çerçevesinde olușur ve vadeli ișlem piyasaları için de bu kavram geçerlidir 
(Hull, 2012). Vadeli ișlem piyasalarında korumacılar, karșılarında riski transfer edebilecekleri spekülatör ya da endeks yatııımcılarını aramaktadırlar. Katılımcıların piyasadaki uzun ya da kısa açık pozisyon verileri, kontratlara olan arz ve talebi direkt anlamamıza yardımcı olmaktadır. Katılımcıların uzun pozisyon alma eğilimleri mala sahiplik isteğini gösterir ve sonuçta dayanak varlığa ait kontrat değerlenir. Tersi durumunda kısa pozisyon alma eğilimleri malı satıs yapma ya da açığa satma isteğini gösterir ve dolayısıyla dayanak varlığa ait kontrat fiyatları düșecektir. Beklentiler modelinde vadeli fiyatlar, alım satıma konu olan dayanak varlığın spot fiyatının vadeli ișlem sözleșmesindeki teslimat gününe kadar ne tutarda değișeceğine ilișkin beklentilere bağlıdır. Yani, beklentiler hipotezine göre kontratın vadeli fiyatı ile vade sonu spot fiyatın aynı olması beklenmektedir. Keynes'in (1930) beklentiler modeline eleștirileri olmuștur. Piyasalarda alıcı ve satıcı olmaları sebebiyle, korumacılar, örneğin çiftçi ve esas tüccarlar nette kısa pozisyonlarda olma eğiliminde olmalarının yanında spekülatörler uzun pozisyonlarda bulunma eğiliminde olmaktadır. Bu ișleyiș iki taraf arasında risk-prim dağııımının olușmasına sebep olmuștur. Keynes, piyasa katılımcılarının pozisyon baskıları sebebiyle birbirlerine ek risk primi ödemeye razı olarak vadeli fiyatların beklenenden farkı olarak değișebileceğini söylemiștir. Literatür genelinde yapılan birçok araștırmada, spekülatörlerin emtia piyasalarında piyasaya likidite sağladıkları ve piyasanın istikrarını bozucu aktivitelerinin genelde olmadığı anlașılsa da emtia ve dönem özelinde spekülatif baskıların emtia fiyatları üzerindeki etkileri de görülmüștür.

Brunetti ve diğerleri (2011), spekülatif hareket eden hedge fonu yatırımcısı ve swap teklifcisi (swap broker) gibi piyasa oyuncularının hareketlerinin fiyat değișimi ve oynaklık üzerine bir etkisi olup olmadığını araștırmıșlardır. Spekülatörlerin finansal piyasaları istikrarsızlaștırdığı üzerine küçük kanıtlar bulmușlardır. Bunun yanında spekülatif ticaretlerin piyasa koșullarına göre tepki göstermekte olduğunu ve spekülatif ticaretin oynaklık seviyelerini düșürdüğünü görmüșlerdir. Bu sonuç spekülatörlerin piyasaya sağladığı likitide hipotezi ile uyumludur. Çalıșmanın detayına bakıldığında, 2005 ile 2009 yılları arasındaki NYMEX'deki petrol ve doğalgaz, CBOT'daki mısır ve eMini-Dow vadeli ișlem kontratlarının günlük getiri verileri üzerinde CFTC'nin yayınladığı vadeli ișlem piyasalarının katılımcılarının pozisyon değișimlerinin ilișkisini arașıımıșlardır. Korelasyon analizi, eșzamanlı modeler ve Granger nedensellik analizleri yöntemlerini kullanmıșlardır. Genel sonuçlar olarak, Granger nedensellik analizlerinde görünen, spekülatif grupların pozisyonların- 
daki değișimler fiyat değișimlerine liderlik etmemektedir. Seçilen vadeli emtia getirilerinde, spekülatif grupların piyasaya likidite sağladığı, piyasayı bozmadığı sonucuna ulașmıșlardır.

Yukarıdaki çalıșmaların yanında, Manera ve diğerleri (2013), 1986-2010 yılları arasındaki 4 enerij (petrol, ısınma yağı, benzin ve doğalgaz) ve 7 tarım (kakao, kahve, mısır, yulaf, soya, soya yağı ve buğday) toplam 11 emtia vadeli fiyat getirileri ile piyasa oyuncularının pozisyonlarının ilișkisini araștırmıșlardır. Veri olarak, emtia verilerinin spekülatif uzun ve spekülatif kısa verilerini haftalık olarak CFTC'den almıșlardır. En yakın kontratın günlük vadeli fiyatları üzerinden haftalık ortalama getiri hesaplayarak, verinin frekansını haftalığa getirmișlerdir. Öncelikle, getirinin bağımlı değișken, pozisyonların bağımsız değișken olduğu EKK regresyon modeli kurmușlardır. Fakat modelde ARCH etkisi olması nedeniyle ve varyans modelleri yardımı ile getiri oynaklığı hakkında bilgi sahibi olmak için koșullu değișen varyans modelleri ile çalıșmıșlardır. Her emtia için genel olarak $\operatorname{GARCH}(1,1)$ modeli kullanmıșlar, ortalama ve varyans modeline dișsal değișken olarak spekülatif net uzun pozisyonları eklemișlerdir. Gaz, kakao ve yulaf emtiasında spekülatif uzun pozisyonların getiri oynaklığını düșürücü etkisi olduğunu; soya ve mısır için spekülatif pozisyonların getiri oynaklığını artırıcı etkisi olduğunu bulmușlardır.

Pamuk emtiasını çalıșmasına dahil eden Guilleminot ve diğerleri (2013), 2006 Ocak ile 2012 Eylül tarihleri arasındaki 12 vadeli emtia için getiri ve endeks oyuncularının ilișkisini incelemișlerdir. Haftalık getiri ile endeks ve spekülatif katılımcılarının pozisyon farklarının ilișkilerini eșzamanlı olarak EKK ve 2SLS ile kurduğu modelde incelemișlerdir. 2SLS yöntemini, ayrıca bağımlı değișkenlerin artıklarının bağımsız değișkenler ile korelasyon ilișkisine sahip olmasından dolayı kullanmıșlardır. 12 emtia içinden EKK yöntemine göre 8 pozisyon değișkeninin katsayısı ve 2LSL yöntemine göre de 7 pozisyon değișkeninin katsayısı anlamlı bulunmuștur. Pamuk özelinde iki yöntem ile de katsayılar anlamlı bulunmuș ve korumacı grupta pozisyon almayan endeks katılımcılarının hareketlerinin fiyat ile pozitif yönlü ilișkide olduğu görülmüștür. Yani pozisyon sayısındaki yukarı yönlü değișim ile getiri yukarı yönlü değișmektedir.

Apperson (2017), 2006 ile 2015 yılları arasında pamuk, soya, mısır ve buğday tarım emtialarını çalıșmıștır. En yakın vadeli kontratın fiyat oynaklıkları ile endeks ticareti yapanların pozisyon oynaklıkları arasında bir Granger nedensellik ilișkisi olup olmadığını araștırmıștır. 
Genel olarak endeks piyasa katılımcılarının pozisyonlarının oynaklıklarının fiyat oynaklıklarına anlamlı bir etkisinin olmadığını görmüștür. Pamuk emtiası özelinde 2008/09 sezonunda endeks katılımcılarının pozisyonlarının artan etkisi fiyat oynaklığını anlamlı olarak artırmıștır. Yani pozisyon değișimi oynaklığın Granger nedeni çıkmıștır. Bunların yanında endeks oyuncularının net pozisyonlarındaki değișimler, kısa ya da uzun, fiyat oynaklığını artırdığını görmüștür.

\subsection{Reel Dinamik Verilerinin Vadeli Emtia Getirileriyle Etkileșimi}

Temel teoride fiyat belirleme yaklașımı, fiyatın arz ve talep arasında olușan denge noktasıdır. Genel anlamda temsil edilen denge noktasının bileșenleri olarak üretim arzı ve tüketim de talebi temsil etmektedir. Bunun yanında, pamuk gibi depolanabilir emtialar söz konusu olduğunda gelecekte beklenen arz ve talep beklentilerine karșı mevcut stokların tutulma isteği de fiyatın belirlenmesinde etkili olacaktır (Janzen, 2013). Bu çalıșmada reel dinamikler bașlığı altında anılan üretim, tüketim ve stok verileri, ABD Tarım Bakanlığı (USDA: United States Depatment of Agriculture) tarafından yayımlanan Dünya Tarım Arz ve Talep Tahminleri (WASDE: World Agricultural Supply and Demand Estimates) raporlarından derlenmiștir. Her ayın 12. günü yıllık sezonsal tahmin verilerinin içeren bu rapor yayınlanmaktadır. Bu veriler dünyanın dört bir tarafındaki ajanslar vasıısısıla USDA tarafından toplanmaktadır. İșlenen araziler, ticaret hacmi, uydu görüntüleri ve iklim koșulları gibi etkenler dikkate alınarak miktarsal tahminleme yapılır. Piyasa katılımcıları her ay USDA tarafından yayınlanan bu emtia raporlarını yorumlayarak vadeli ișlem piyasalarında pozisyonlarını almaktadırlar. Temel teoriye göre, talebin (tüketimin) artması fiyatları arttıracağı, arzın (üretimin) artması fiyatları azaltacağı ve emtiaya özel olarak stokların artması (düșük talep yüksek arz) sebebiyle fiyatları azaltacağı yönündedir.

Macdonald (2009), ABD çiftlik arazi pamuğu fiyatlarının tahmini için fiyatın bağımlı değișken olduğu, $A B D$ pamuk arzının, $A B D$ stok/ kullanım oranının ve Çin net ithalat verisinin bağımsız değișken olduğu tahmin modeli olușturmuștur. 1973 ile 2007 yılları arası arazi pamuk fiyatları tarihsel verileri USDA'nın Ulusal Tarım İstatistik Servisi (NASS: National Agricultural Statistics Service)'den ve miktar verilerini USDA'nın WASDE raporundan almıștır. Macdonald, $A B D$ arz verisini ithalatlar ve üretim olarak, $A B D$ talep verisini ise ihracat ve tüketim olarak almıştır. Bir ülke özelinde düșünüldüğünde, arz ve talebi MacDonald gibi gruplamak mantıklıdır. Ülke'nin ekonomisine fiziki pamuk olarak giren 
pamuk emtiası miktarını arz olarak (ya da üretim ve ithalat toplamı) tanımlanırken, ülkenin ekonomisinden fiziki pamuk olarak çıkan pamuk emtia miktarını talep olarak (ya da tüketim ve ihracat toplamı) tanımlamıștır. USDA'da WASDE raporunda bu aynı gruplamayı yapmıștır. Macdonald, fiyatın \%68'i pamuk fiyat modelinde kullanılan değișkenler ile açıkladığını söylemektedir. Modelde ABD pamuk arzı ve Çin net ithalat verisi olasılık değerleri anlamlı çıkmıștır, ABD stok kullanım oranı anlamlı çıkmamıștır. Arzdaki yüzdelik artıșların, fiyatı yüzdelik olarak düșürdüğünü ve Çin net ithalatındaki yüzdelik artıșların, fiyatı yüzdelik olarak arttırdığını söylemiștir. Macdonald, ABD arz ve talep reel dinamiklerinin $A B D$ arazi pamuk fiyatına etkilerini göstermiștir. Bu çalıșmada ise dünya pamuk reel dinamiklerinin vadeli pamuk emtia ișlem fiyatlarına etkisi araștırılmıștır.

Chua ve Tomek (2010), gelecekteki ekonomik beklentilerin emtia fiyatlarını etkileyen önemli bir unsur olduğu düșünerek mısır emtiasının vadeli ișlem fiyatlarının beklenen üretim, stok ve talep verileri ile nasıl etkilendiğini ortaya koymak için ekonometrik model çalıșmıșlardır. 1989 ile 2009 yılları arası mısır vadeli ișlem fiyatlarını CBOT'dan ve beklenen üretim, stok ve tüketim verilerini USDA'nın WASDE raporundan temin etmișlerdir. Fiyatın bağımlı değișken olduğu modelde, beklenen arz artıșları olduğunda vadeli mısır emtia fiyatlarının düștüğünü görmüșlerdir.

Janzen (2013) araștırmasında net arz șoklarının pamuk fiyatlarını arttırdığından bahsetmiș ve pamuk fiyatlarının așırı yükselmesinde ya da düșüșünde mevcut stok miktarlarının da etkisi olduğunu söylemiștir. Ayrıca, 2008 yılında istisna yașanarak talep kaynaklı bir fiyat yükselișinin olduğunu söylemektedir. Janzen, araștırmasını 1960 ile 2011 yılları arasındaki aylık veriler üzerinden çalıșmıștır. Fiyat verileri için en yakın vadedeki pamuk vadeli ișlem kontratlarını almıștır. Reel ekonomik dinamikler olarak bahsettiği arz ve talep verileri için USDA raporlarını kullanmıștır. Bulgularına göre; reel ekonomik aktivitilerin pamuk fiyatlarının değișiminde etkili olduğunu ve bu arz talep değișimlerinin dönemlere göre fiyatların yüksek oynaklığına sebep olduğunu söylemiștir. 1973/74, 1990/91 , 1995/96, 2010/11 sezonları için net arz șoklarının pamuk vadeli emtiası fiyatının en fazla değișmesinde etkili olduğu sezonlar olduğunu söylemiștir. Fakat 2007/08 sezonunda net arz șoklarının fiyatların sapmalarında etkili bir sebep olmadığını belirtmiștir. Bu çalıșmada, Jansen'in de bulguları arasında olan, talep ve stok/kullanım reel dinamiklerinin getiriyi etkilediği görülmüștür. 
Jacks ve Stuermer (2016), yaptıkları çalıșmada geniș bir veri aralığı kullanmıștır. 1870'den 2013 yılına kadar 145 yılı kapsayan ve çeșitli tarım, metal ve hafif emtialardan olușan 12 emtia verisi ile çalıșmıșlardır. Aylık veriler üzerinde yapısal VAR modeli kullanmıșlardır. Emtia talep ve stok șoklarının, arz șoklarından ziyade reel emtia fiyat yükselișlerinin öncü tetikleyicisi olduğunu anlamıșlardır. Özellikle tarım ve pamuk gibi hafif tarım emtia ürünleri için stok ve emtia özelinde talep șoklarının fiyat yükselișlerinin önemli bir sürücüsü olduğunu belirtmektedirler. Farklı emtialarda talep șoklarının fiyat farklılașmasına katkısı olduğunu söylemektedirler. Bu çalıșmada da Pamuk emtiası özelinde benzer sonuçlar çıkmıștır. Stok/kullanım ve talep verilerinin getiri ile ilișkili olduğu, arz verilerinin getiri üzerinde etkili olmadığı anlașılmıștır.

\section{Veri ve Ekonometrik Yöntem}

\subsection{Veri}

Veri aralığı olarak küresel krizin boy gösterdiği 2008 yılından sonraki 2009-2018 yılları çalıșmada kullanılmıștır. Fiyat verileri için NYSE:ICE borsasında ișlem gören Pamuk no.2 günlük kapanıș verileri kullanılmıștır. Yıl içerisinde ișlem gören sırasıyla mart, mayıs, temmuz, ekim ve aralık vadeli kontratlarının en yakın vadeli olanlarından derlenmiștir. Çalıșmada kullanılan bağımsız değișkeni temsil eden haftalık COT pozisyon verileri, en yakın vadeli ve sonraki tüm kontratlar için pozisyon sayılarını raporlamaktadır. Tüm vadelerdeki kontrat ağırlıklarına göre en yüksek pozisyon verileri en yakın vadeli kontratta ișlem görmesi (Lehecka, 2013) ve bununla birlikte genel olarak literatürde en yakın vadeli ișlem fiyatları kullanılması nedeniyle bu çalıșmada da en yakın vadeli kontrat fiyat verisi kullanılmıștır. Fiyat verilerinden logaritmik getiri verileri elde edilmiștir. Aylık vadeli pamuk getiri verisi modellerde "G_A" olarak gösterilmektedir.

Spekülatörlerin pozisyon verileri her haftanın Cuma günü yayınlanan CFTC'nin COT-Ek raporunda uzun ve kısa açık pozisyon olarak CFTC'nin internet sitesi üzerinde halkın kullanımına açık olarak paylașılmaktadır. Pozisyon değișimi değișkenleri arasından korumacı olmayanlar -spekülatörler ve endeks yatırımcıları- net uzun pozisyon verileri (KXN_AY) ve spekülatör kısa pozisyon verileri (SPK_AY), haftalık yayınlanan CFTC'nin COT-Ek raporundan aylık toplamların yüzdesel değișimi olarak derlenmiștir. Korumacı olmayan uzun net pozisyonlar (KXN_AY) ve spekülatif kısa pozisyonlar (SPK_AY) için orijinali haftalık frekansta olan veriler, aylık toplanarak değișim çevrimi yapılmıștır ve veriler aylık 
frekansa çevrilmiștir. Aylık pozisyonların logaritmik ve yüzdesel değișim farkları üzerinden araștırmalar yapılmıștır (Tablo 1).

Tablo 1: CFTC'nin COT-Ek raporundan temin edilen katılımcı pozisyon verileri

\begin{tabular}{|l|l|l|}
\hline COT Raporu Pozisyon Adı & Kısalłma & Modellerde Kullanılan Dönüșümler \\
\hline $\begin{array}{l}\text { Non-commercial long - spekü- } \\
\text { latif uzun }\end{array}$ & SPU & Spekülatör aylık uzun pozisyon sayıları \\
\hline $\begin{array}{l}\text { Non-commercial short - spekü- } \\
\text { latif kısa }\end{array}$ & SPK & Spekülatör aylık kısa pozisyon sayıları \\
\hline $\begin{array}{l}\text { Index trader long - endeks yatı- } \\
\text { rımcılar uzun }\end{array}$ & EOU & Endeks Katılımcıları aylık uzun pozisyon sayıları \\
\hline $\begin{array}{l}\text { Index trader short - endeks ya- } \\
\text { tırımcılar kısa }\end{array}$ & EOK & Endeks Katılımcıları aylık kısa pozisyon sayıları \\
\hline $\begin{array}{l}\text { Non-commercial short - spekü- } \\
\text { latif kısa }\end{array}$ & SPK_AY & $\begin{array}{l}\text { Aylık spekülatör kısa pozisyonların LN farkları : } \\
\text { LN(SPK(t) / SPK(t-1)) }\end{array}$ \\
\hline $\begin{array}{l}\text { Non Hedgers Net - korumacı- } \\
\text { lar hariç net }\end{array}$ & KXN_AY & $\begin{array}{l}\text { (SPU(t) - SPK(t) + EOU(t) - EOK(t)) / (SPU(t-1) - } \\
\text { SPK(t-1) + EOU(t-1) - EOK(t-1)) }\end{array}$ \\
\hline
\end{tabular}

Pamuk reel piyasa dinamikleri olarak nitelendirilen arz ve talep verileri ve bunlarla birlikte pamuğun stoklanabilen bir emtia olması sebebiyle dönem sonu stok verileri, USDA'nın WASDE beklenti raporundan alınmıștır. Raporun içeriğinde, dünya ve ülke bazında sezon sonu itibariyle yıllık beklenen üretim, tüketim, ihracat, ithalat ve dönem sonu stok tahminleri yer almaktadır. Aylık olarak yayınlanan WASDE raporunda dünya toplamının ve ülkelerin emtia arz ve talepleri tam bir bilanço tutarlılığında raporlanmaktadır ve nihayetinde bu raporda arz ve talep birbirine denkleștirilmiștir. Pamuk vadeli getirisinin, talep ve stok/kullanım verileri ile anlamlı sonuçlar verdiği görülmüștür (Özaydın, 2019). Bu çalıșmada arz verisi dıșarıda bırakılmıș ve kurulacak model üzerinde tüketim ve stok/kullanım verileri çalıșılmıștır. Çin'in geçen son 10 yılda ortalama pamuk üretiminde ve tüketiminde dünya lideri olmasının ve Çin'in reel dinamik verilerinin USDA'nın pamuk raporlarında özellikle paylașılmasının vadeli pamuk emtiası fiyatları üzerinde etkisi olduğu düșünülmektedir. Bununla birlikte Çin dıșında kalan ülkelerin de konsolide etkisi incelenmiștir. Kullanılan veriler tablo 2'de gösterilmiștir. Konsolide dünya talep verisi, Çin tüketim (CUS) ve Çin dıșı ülkeler talep (XCD) bilgilerinin toplamını içermektedir ve bu veriler çalıșmaya dahil edilmiștir. Konsolide dünya stok/kullanım verisini olușturan iki tamamen ayrıșık veri olan Çin stok/kullanım (CSU) ile Çin dıșı ülkeler stok/kullanım (XCR) verileri çalıșmaya dahil edilmiștir. Bunlarla birlikte, dünya konsolide ihracat ve ithalat verileri arasındaki korelasyon \%99.96 çıkmıștır -ülkeler 
arası karșılıklı ticaretin toplamda eșit olması beklenen bir durumdur- ve dünya ithalat (WIM) verisi çalıșmaya dahil edilmiștir. Özetle bu bölümde incelenecek pamuk reel dinamik verileri olarak CUS, XCD, CSU, XCR ve WIM verileri olmuștur.

Tablo 2: USDA'nın WASDE raporundan temin edilen pamuk reel piyasası verileri

\begin{tabular}{|l|l|l|}
\hline WASDE Raporu Verileri & Kısaltma & Açılklama \\
\hline Çin Talep (Tüketim) & CUS & $\begin{array}{l}\text { Çin'in tüketim verisi, LN farkı (Çin'in ih- } \\
\text { racatı yoktur) }\end{array}$ \\
\hline Çin Hariç Talep (Tüketim + İhracat) & XCD & $\begin{array}{l}\text { Çin hariç ülkeler tüketim ve ihracat top- } \\
\text { lamı LN farkı }\end{array}$ \\
\hline Çin Dönem Sonu Stok / Kullanım & CSU & Çin stok/kullanım rasyosunun LN farkı \\
\hline Çin Hariç Dönem Sonu Stok / Kullanım & XCR & $\begin{array}{l}\text { Çin hariç ülkeler stok/kullanım rasyosu- } \\
\text { nun LN farkı }\end{array}$ \\
\hline Dünya İthalat : World Import & WIM & Dünya toplam ithalat verilerinin LN farkı \\
\hline
\end{tabular}

\subsection{Ekonometrik Yöntem}

Değișkenlerin birim kök analizleri sonrasında kurulan EKK modellerin kalıntılarında görülen ARCH etkisi sorunu sebebiyle koșullu değișen varyans modelleri kullanılmıștır. ARCH ve GARCH modelleri, değișken oynaklığa sahip finansal zaman serileri için varyansın sabit kalmadığını öngören ve doğrusal olmayan ekonometrik modellerdir. ARCH modelleri finansal piyasa analizlerinde yaygınca kullanılan bir yöntemdir. Literatürde yapılan çalıșmalarda finansal zaman serileri üzerine sık kullanılan ARCH, GARCH modelleri yanında en iyi modeli tahmin etmek amacıyla diğer sıkça kullanılan EGARCH ve TGARCH modelleri de kullanılmıștır. Koșulları sağlayan en uygun model seçilerek katsayılar üzerinde yorumlamalar yapılmıștır. Denenen koșullu varyans modelleri içinde koșulları sağlayan ve test kriterlerine göre anlamlı sonuç veren EGARCH modeli seçilmiștir.

GARCH modelleri, pozitif ve negatif șoklara karșı oynaklığın simetrik tepki verdiğini varsaymaktadır. Fakat bu varsayımın geçerli olmadığı ihtimaller de mümkündür ve oynaklığın olası șoklara karșı asimetrik tepki verdiği durumlar da söz konusudur. Finansal zaman serilerindeki kaldıraç etkisinin modellenmesinde yeterli olamayan GARCH modelleri yerine ilk olarak Nelson (1991) tarafından bu eksikliğin giderilmesi için üstel GARCH (EGARCH) modelleri geliștirilmiștir. 


$$
\log \left(h_{t}\right)=\omega+\sum_{j=1}^{p} \beta_{j} \log \left(h_{t-j}\right)+\sum_{i=1}^{q} \alpha_{i} \frac{\left|u_{t-i}\right|}{\sqrt{h_{t-i}}}+\sum_{i=1}^{q} \gamma_{i} \frac{u_{t-i}}{\sqrt{h_{t-i}}}
$$

EGARCH modelinde koșullu varyansın doğal logaritması kendi gecikmeli değerlerine ve gecikmeli hata terimi karesi yerine standartlaștırılmıș hata terimine koșulludur. Aynı zamanda koșullu varyans $h_{t^{\prime}}$ gecikmeli hata terimlerinin hem büyüklügüne hem de ișaretine bağlıdır. EGARCH modelinde koșullu değișen varyansın logaritması alındığından parametreler pozitif olmaktadır. Bunun sonucu olarak $A R C H$ ve $G A R C H$ modellerindeki parametrelerin $O^{\prime}$ dan büyük olma koșulu $\left(\alpha_{i}\right.$ ve $\beta_{i}$ parametrelerinde sınırlamalar yoktur) gerekmemektedir (Brooks, 2008, s. 406). Burada $\gamma i \neq 0$ ise, asimetrik etkinin bulunduğunu ve $\gamma i<0$ ise kaldıraç etkisinin olduğunu söylemektedir. Yani aynı büyüklükteki negatif șokların oynaklığa etkisinin pozitif șoklardan daha fazla olduğunu ișaret etmektedir. Ayrıca 'nin mutlak değerinin küçük olması oynaklığın kalıcılığının (sürekliliğinin) az olduğunu göstermektedir (Özden, 2008).

Kurulan model dıșında veriler arasında Granger nedenselliğin olup olmadığı ayrıca incelenmiștir. Granger (1969), nedensellik analizinde iki değișken arasındaki ilișkinin kuvveti dıșında, bu ilișkinin değișkenler arasındaki yönünü de kapsamaktadır. Granger pragmatik ve ișlevsel bir yaklașımla iki seri arasında nedensellik ilișkisini ortaya koymuștur. Granger nedensellik kavramı șu șekilde açıklanır: İki zaman serisinden, St ve Rt; Rt serisi kendi gecikmeleri dıșında bașka bir St serisinin gecikmeleri ile dahi iyi tahmin edilebiliyorsa; St, Rt'nin Granger nedenidir. Getiri ve pozisyon verilerinin, Akaike, Schwarz, Hannan-Quinn bilgi kriterlerine bakılarak gecikme uzunlukları bulunmuștur. Serilerin Granger nedensellik testi yapılmadan önce kendi seviyelerinde durağan olması gereklidir.

\section{Bulgular}

Aylık pozisyon değișimleri ile aylık reel dinamik verilerinin bağımsız değișken olduğu, aylık toplam vadeli fiyat üzerinden olușturulmuș getiri serilerinin bağımlı değișken olduğu koșullu değișen varyans modelleri kurulmuștur. Ortalama model üzerinden bağımsız değișkenlerin, bağımlı değișken olan getiri üzerindeki etkileri karșılaștırılmıștır. Varyans modeli sayesinde getiri oynaklığının, getirinin hata terimi kareleri ve gecikmiș varyansı ile etkileșimi incelenmiștir. Devam eden bölümde, getiri ile diğer veriler arasında Granger nedensellik analizlerine bakılıp veriler arası etkileșim yönü anlașılmaya çalıșılmıștır. Çalıșmada Eviews ekonometrik modelleme uygulaması kullanılmıștır. 


\subsection{Birim Kök, Otokorelasyon Sınaması}

Vadeli pamuk emtiası aylık getiri verisinin, pozisyon serilerinin ve reel dinamik serilerinin durağan olup olmadıklarına bakılmıștır. Genișletilmiș Dikey Fuller (ADF), Phillips-Perron (PP) ve Kwiatkowski-PhillipsSchmidt-Shin (KPSS) testleri kullanılarak serilerde sabitli birim kök araștırması yapılmıștır. Bu bölümde kullanılan aylık getiri, pozisyon değișimleri ve reel dinamik değișimleri serilerinin birim kök içermediği yani verilerin durağan olduğu görülmüștür (Tablo 3).

Tablo 3: Aylık Pozisyon ve Reel Dinamik Verilerinin Birim Kök Analizi Test İstatistik Tablosu

\begin{tabular}{|l|c|c|c|}
\cline { 2 - 4 } \multicolumn{1}{c|}{} & \multicolumn{3}{c|}{ Sabit Terimli Birim Kök Test İstatistik Sonuçları } \\
\cline { 2 - 4 } \multicolumn{1}{c|}{} & ADF & PP & KPSS \\
\cline { 2 - 4 } & t-İstatistik & t-Istatistik & t-İstatistik \\
\hline G_A & -7.5392 & -7.8012 & 0.1614 \\
\hline KXN_AY & -9.2302 & -9.1401 & 0.0521 \\
\hline CUS_AY & -9.4469 & -9.9010 & 0.0539 \\
\hline XCD & -8.4488 & -8.7011 & -9.9214 \\
\hline CSU & -10.0923 & -10.3854 & 0.1107 \\
\hline XCR & -5.0812 & -8.0980 & 0.3636 \\
\hline WIM & -9.7440 & -10.0877 & 0.1014 \\
\hline
\end{tabular}

* Tüm seriler için birim kök yoktur, sonuçlar tüm testlerde \% 1 olasılık düzeyinde anlamlıdır.

Bir zaman serisi değișkeninin gecikmeli değerleri arasındaki birlikte değișimin bir ölçüsü otokorelasyon ve otokovaryans olarak adlandırilır (Sevütekin \& Nargeleçekenler, 2010, s. 251). Kurulan bir modelin sağlıkı olabilmesi için hata terimlerinin kovaryansı sıfır olmalıdır yani hata terimleri istatistiksel olarak birbirlerinden etkilenmemeli, otokorelasyon sorunu olmamalıdır. Seri LM testi hipotezi; HO: hipotezi kalıntılar arasında otokorelasyon yoktur șeklinde kurulurken, $\mathrm{Hl}$ : hipotezi otokorelasyon varlığını kabul eder. G_A aylık getiri serisi için otokorelasyon olup olmadığı tespit etmek amacıyla sabitti kurulan;

$$
\mathrm{G}_{-} \mathrm{A}_{\mathrm{t}}=\mathrm{C}+\varepsilon_{\mathrm{t}}
$$

modelinde bir gecikmeli seri korelasyon $L M$ testi sonucunda, T'nin gözlem sayısı olduğu yerde, $T^{*} R^{2}$ değeri 14.3656 ve Ki-Kare olasılık değeri \%0 sonucu vermișțir. İkinci gecikme için de olasılık değeri \%0 çıkmıștır. 
$\mathrm{HO}$ reddedilir, modelin kalıntılarında ya da seride otokorelasyon sorunu ortaya çıkmaktadır. Bu sorunu bağımlı değișkenin kendi geçmiș değerleri modellere eklenerek giderilebilmektedir. Program yardımıyla model (2) üzerinde yapılan sabitli ve gecikmeli AR ve MA modeli kombinasyon denemelerinde $A R(1)$ modeli en düșük Schwarz kriter değerini vermiștir (Tablo 4). Ayrıca G_A getiri serisinin kolegram grafiği incelendiğinde birinci dereceden gecikme olduğu da görülmüștür.

Tablo 4. Vadeli Pamuk Aylık Getirisinin (G_A) ARMA Gecikmeleri Schwarz Kriter Tablosu

\begin{tabular}{|c|c|c|c|c|c|c|c|c|c|c|c|}
\hline AR / MA & 0 & 1 & 2 & 3 & 4 & 5 & 6 & 7 & 8 & 9 & 10 \\
\hline 0 & -2.5597 & -2.5893 & -2.5772 & -2.5676 & -2.5386 & -2.4959 & -2.4533 & -2.4255 & -2.4002 & -2.4059 & -2.3763 \\
\hline 1 & -2.6289 & -2.6060 & -2.5662 & -2.5345 & -2.4959 & -2.4845 & -2.4440 & -2.4043 & -2.4224 & -2.3938 & -2.3517 \\
\hline 2 & -2.6058 & -2.5649 & -2.5653 & -2.5459 & -2.5094 & -2.4550 & -2.4020 & -2.3998 & -2.3936 & -2.3695 & -2.3270 \\
\hline 3 & -2.5671 & -2.5248 & -2.5435 & -2.5157 & -2.4677 & -2.4308 & -2.3750 & -2.3358 & -2.3585 & NA & -2.2880 \\
\hline 4 & -2.5269 & -2.5318 & -2.4893 & -2.4690 & -2.4180 & -2.3854 & NA & -2.3145 & -2.3123 & NA & -2.2456 \\
\hline 5 & -2.5102 & -2.4725 & -2.4299 & -2.4537 & -2.4122 & -2.3658 & NA & NA & -2.2729 & -2.2577 & NA \\
\hline 6 & -2.4716 & -2.4300 & -2.3960 & -2.3869 & -2.3704 & -2.3487 & NA & -2.2816 & -2.2786 & NA & -2.1927 \\
\hline 7 & -2.4293 & -2.3873 & -2.3749 & -2.3462 & -2.3310 & NA & -2.2793 & -2.2405 & -2.1841 & -2.2183 & -2.1785 \\
\hline 8 & -2.4084 & -2.3659 & -2.3539 & -2.3180 & -2.3015 & -2.2886 & -2.2455 & NA & -2.2045 & -2.1815 & -2.1417 \\
\hline 9 & -2.3665 & -2.3477 & -2.3252 & -2.2849 & -2.2464 & -2.2402 & -2.1996 & -2.1920 & -2.1756 & -2.1397 & NA \\
\hline 10 & -2.3491 & -2.3128 & -2.2748 & -2.2609 & -2.2182 & -2.1976 & -2.1864 & NA & -2.1369 & -2.1028 & -2.0606 \\
\hline
\end{tabular}

* İterasyon sonucunda Schwarz kriteri en düșük veren AR(1) çıkmıștır.

$A R(1)$ süreci olarak getirinin 1 gecikmesinin eklendiği model așağıdaki gibi olușmuștur:

$$
\mathrm{G}_{-} \mathrm{A}_{\mathrm{t}}=\mathrm{C}+\theta^{*} \mathrm{G}_{-} \mathrm{A}_{\mathrm{t}-1}+\varepsilon_{\mathrm{t}}
$$

$A R(p)$ süreçlerinde otokorelasyon fonksiyonu, MA(q) otokorelasyon fonksiyonu gibi koșullu değildir ve p gecikme sonrası için otokorelasyon fonksiyonunun sıfır ya da sıfıra çok yakın bir değer verdiği kontrol edilmelidir (Sevütekin \& Nargeleçekenler, 2010, s. 143, 165). Denklem 3'deki modelin iki gecikmeli otokorelasyon testi için Seri LM testi yapılmıștır. Test istatistik sonuçlarında $T^{*} R^{2}$ değeri 2.4142 ve KiKare olasılık değeri \%29.91 çıkmıștır. Bu test sonuçlarına göre, G_A serisinde $A R(1)$ süreci uygulanmasıyla otokorelasyon kalkmıștır. Ayrıca kaleogram grafiğinde de otokorelasyonun kalktığı görülmüștür.

\subsection{Getirinin, Pozisyon ve Reel Dinamiklerle Birlikte Modellenmesi}

Toplam 120 aylık veri serilerinden olușan piyasa oyuncuları verileri (KXN_AY, SPK_AY) ile reel dinamik verileri (CUS, XCD, CSU, XCR, WIM), kurulan EKK modelinde bağımsız değișken olarak kullanılmıș, 
vadeli ișlem fiyat getirisi G_A bağımlı değișken olacak șekilde modellenmiștir.

G_A $=$ C $+\theta_{1}$ KXN_AY $+\theta_{2}$ SPK_AY $+\theta_{3}$ WIM $+\theta_{4}$ CSU $+\theta_{5} \mathrm{CUS}+$ $\theta_{6} \overline{\mathrm{XCR}}+\theta_{7} \mathrm{AR}(1)$

Kurulan ilk modelde WIM, CUS ve XCD verileri istatistiki olarak \%10 olasılık değeri üzerinde anlamsız çıkmıștır. Bu durumda anlamlı sonuçlar veren diğer değișkenlerle kurulan yeni EKK modeli așağıdaki gibi olușmuștur. Son modelde değișken katsayıları \% 10 olasılık düzeyinde anlamlıdır (Denklem 5). ilerleyen kısımlarda bu modelde ARCH etkisi olup olmadığına bakılacaktır.

$\mathrm{G} \_\mathrm{A}=\mathrm{C}+\theta_{1} \mathrm{KXN} \_\mathrm{AY}+\theta_{2} \mathrm{SPK} \_\mathrm{AY}+\theta_{3} \mathrm{CSU}+\theta_{4} \mathrm{XCR}+\theta_{5} \mathrm{AR}(1)$ (5)

Sağlıkı bir model kurulabilmesi adına bağımsız değișkenler arasında çoklu doğrusal bağıntı sorunu olmaması gerekmektedir. Seri korelasyon ve ARCH etkisi sınaması yanında, EKK yöntemi ile kurulan modelde birden fazla bağımsız değișken bulunması sebebiyle çoklu doğrusal bağlantı sorunu olması ihtimaline karșı varyans büyütme faktörü (VIF: Variance Inflation Factor) testi yapılmıștır. Regresyon analizi sırasında VIF, faktörlerin birbirleriyle korele olup olmadığını (multicollinearity) değerlendirir, bu da p-değerlerini etkileyebilir ve model güvenilir olmayacaktır. Bağımsız değișkenler arasındaki çoklu doğrusal bağlantının varlığını tespit etmek için varyans büyütme faktörü (VIF) değerleri kontrol edilmektedir. Araștırmacının kriterlerine göre değișmesi ile birlikte, Hair ve diğerleri (1995) bir modeldeki bağımsız değișkenler arasında çoklu doğrusal bağlantı olmaması için VIF değerinin maksimum "10" olmasını önermișlerdir. Modellerde birden fazla bağımsız değișken olduğu için bu değișkenler arasında çoklu doğrusal bağıntı olup olmadığını anlamak üzere VIF değerleri incelenmiș, sonuç değerlerin 1 ile 2 arasında olduğu görülmüștür. Kurulan modelde değișkenler arası çoklu doğrusal bağıntı sorunu görülmemiștir (Tablo 5).

Tablo 5. Çoklu Doğrusal Bağıntı Testi VIF Değerleri

\begin{tabular}{|l|c|c|c|c|c|}
\hline Değișken: & KXN_AY & SPK_AY & CSU & XCR & AR(1) \\
\hline VIF Değerleri: & 1.5945 & 1.8753 & 1.2147 & 1.4873 & 1.3679 \\
\hline
\end{tabular}

Heteroskedasticity (değișen varyans) etkisi, dağılımı sivri ve kuyruklu olan yüksek frekanslı finansal getiri verilerinde görülmektedir (Gökbulut \& Pekkaya, 2014). Șekil 1'deki aylık getirilerden olușan G_A serisinin histogramına ve normal dağılımına bakıldığında basıklığı ifade 
eden kurtosis sayısı 6.905303 çıkmıștır. Bir seride kurtosis değeri 3'ten fazla ise bu serinin yanlardan basık ve sivri olduğu söylenebilmektedir. Seride ARCH etkisinin görülmesinin ihtimali yüksektir. ARCH yöntemi kullanılmadan önce ortalama modelin $\mathrm{ARCH}$ etkisini içerip içermediği test edilmelidir.

\section{Șekil 1. Aylık Getiri Serisinin Histogramı ve Normal Dağılımı}

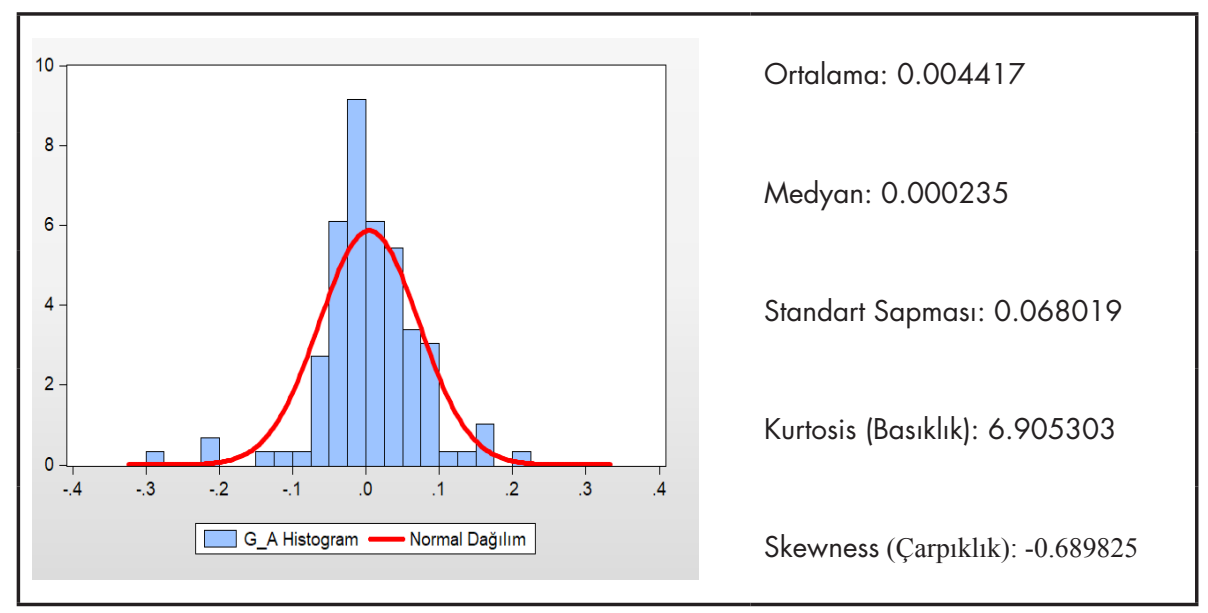

EKK üzerinde kurulan modelde (Denklem 5) ARCH etkisinin olup olmadığı ARCH LM testi ile kontrol edilmiștir. EKK modeli üzerinde görülen $A R C H$ etkisi $L M$ test sonuçları tablo 6'da görülmektedir. Beșinci gecikmede hipotez reddedilir ve $\mathrm{ARCH}$ etkisi vardır denilir. Bu sonuçların devamında, değișkenlere uygun koșullu varyans modeli belirlendikten sonra ARCH LM testleri tekrar yapılmıștır.

Koșullu değișen varyans modelleri arasından $\mathrm{ARCH}, \mathrm{GARCH}$, TGARCH ve EGARCH modelleri farklı arch ve garch gecikmeleri ile denenmiștir. Koșulları sağlayan, Akaike ve Schwarz test kriterlerinin düșük olduğu ve varyans denkleminin değișkenlerinin anlamlı sonuçlar verdiği model $\operatorname{EGARCH}(1,1)$ modeli olarak tespit edilmiștir. Kurulan koșullu değișen varyans modelinde ARCH etkisi olup olmadığı tekrar kontrol edilmiștir ve $\mathrm{ARCH}$ etkisinin beșinci gecikmede kalktığı görülmüștür (Tablo 6). Kurulan modelin kalıntılarının dağılımı normaldir. Jarque-Bera test hipotezine göre, test istatistiğinin olasılık değerinin \%10'dan büyük olması dağılımın normal olduğunu göstermektedir (Șekil 2). Dağılımın kurtosisi 3.3178 çıkmıștır, normal dağılımda kurtosis 3 değeri olması beklenir. Hata terimlerinin dağılımın kurtosisinin 3'den kısmen büyük olması finan- 
sal serilerde görünen leptokurtik dağılıma (yanlardan basık ve sivri) örnek teșkil etmektedir. Bununla birlikte kurtosis değeri 3'e yakın çıkmıștır.

Tablo 6. Kurulan EKK ve EGARC $(1,1)$ modelinde Arch LM Sinaması Test İstatistiki Sonuçlar

\begin{tabular}{|l|l|l|l|}
\hline Model & Gecikme & T*R-kare & Ki-Kare olasılık \\
\hline EKK & 1 & 0.0527 & 0.8185 \\
\hline EKK & 5 & 20.6047 & 0.0010 \\
\hline EGARCH $(1,1)$ & 1 & 0.0920 & 0.7617 \\
\hline EGARCH $(1,1)$ & 5 & 1.4061 & 0.9236 \\
\hline
\end{tabular}

Șekil 2. Kurulan $\operatorname{EGARCH}(1,1)$ Modelinin Kalıntılarının Histogramı ve JarqueBera Test Sonuçları

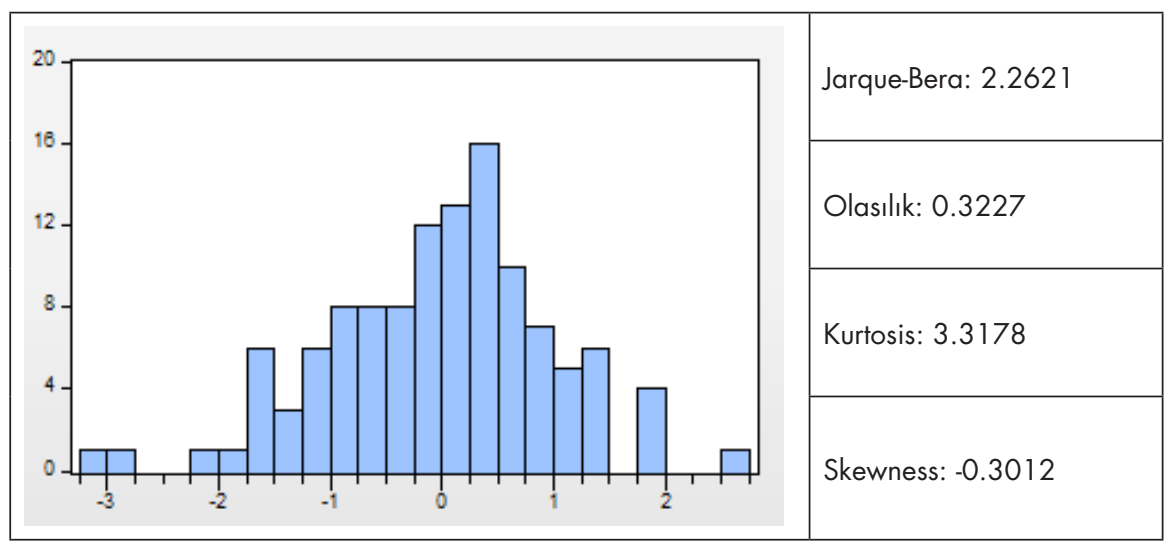

Ortalama modelde bağımsız değișkenler \% 10 olasılık seviyesinde anlamlı çıkmıștır. Tablo $7^{\prime}$ de $\operatorname{EGARCH}(1,1)$ modelinin istatistiki sonuçları görülmektedir. Model üzerinde, korumacı olmayanların (spekülatör ve endeks yatırımcıları) uzun net pozisyonlarındaki (KXN_AY) yüzde 1'lik bir artıș getiride yüzde $0.0686^{\prime}$ lık bir artıșa neden olmaktadır. Spekülatörlerin kısa pozisyonlarındaki yüzde 1'lik bir artıș getiride eksi yüzde $0.0317^{\prime}$ lik bir düșüsse neden olmaktadır. Uzun pozisyonların getiri üzerindeki mutlak etkisi kısa pozisyonlara göre daha fazladır. Reel dinamik verilerini incelediğimizde, modelde sadece stok/kullanım oranları anlamlı sonuçlar vermiștir. Çin dıșı ülkeler stok/kullanım oranındaki (XCR) yüzde $1^{\prime}$ lik bir artıș getiride eksi yüzde 0.2664'lük bir düșüșe neden olmaktadır. Çin stok/kullanım oranlarındaki (CSU) yüzde 1'lik bir artıș getiride eksi yüzde 0.1299'luk bir düșüșe neden olmaktadır. Yani stok/ kullanım oranlarının yükselmesi, bir bașka açıdan stokların yükselmesi, 
getiriyi düșürmektedir. Çin dıșı ülkelerin stok/kullanım oranlarının, Çin stok/kullanım oranına göre getiri üzerinde daha etkili olduğu görülmektedir. Spekülatif pozisyon değișimlerinin getiri üzerinde etkisi var ise de bir reel dinamik değișkeni olan stok/kullanım oranları kadar getiri üzerinde etkisi görülmemiștir. Varyans modelinde sabit hariç arch ve garch değișkenlerinin katsayıları \%10 olasılık seviyesinde anlamlı çıkmıștır. Modelin geçmiș varyansı ve hata terimlerinin kareleri getiri oynaklığını etkilemektedir.

Tablo 7. Aylık Getirinin (G_A) Bağımlı Değișken Olduğu EGARCH(1,1) Model İstatistikleri

\begin{tabular}{|l|c|c|c|c|}
\hline Bağımsız Değișken & Katsayı & Std. Hata & z-istatistik & Olasılık \\
\hline \multicolumn{5}{|l|}{ Ortalama Denklem } \\
\hline C & 0.0033 & 0.0036 & 0.9150 & $36 \%$ \\
\hline KXN_AY & 0.0686 & 0.0237 & 2.8932 & $0 \%$ \\
\hline SPK_AY & -0.0317 & 0.0171 & -1.8550 & $6 \%$ \\
\hline XCR & -0.2664 & 0.1186 & -2.2466 & $2 \%$ \\
\hline CSU & -0.1299 & 0.0571 & -2.2750 & $2 \%$ \\
\hline AR(1) & 0.1584 & 0.0902 & 1.7557 & $8 \%$ \\
\hline Varyans Denklemi & & & & \\
\hline$\Omega$ & -0.1073 & 0.0713 & -1.5044 & $13 \%$ \\
\hline A & -0.1442 & 0.0878 & -1.6416 & $10 \%$ \\
\hline$\gamma$ & 0.1543 & 0.0358 & 4.3052 & $0 \%$ \\
\hline$\beta$ & 0.9679 & 0.0014 & 710.7136 & $0 \%$ \\
\hline
\end{tabular}

\subsection{Granger Nedensellik Analizi}

Serilerin Granger nedensellikleri ikili kombinasyonlarda bakılmıștır. Verilerin gecikmeleri Akaike, Schwarz, Hannan-Quinn bilgi kriterlerine bakılarak bulunmuștur ve bulunan bu gecikmeler Granger nedensellik analizleri için kullanılmıștır. Modellerdeki gecikme sayısının belirlenmesinde genel olarak Schwarz kriteri dikkate alınmıș olup tüm modeller için bir gecikme alınmıștır. Schwarz, 7 modelin 6'sında "bir" gecikme vermiștir; diğer model için Hannan-Quinn ve Akaike test istatistik sonuçlarına bakılarak kalan bu model için de bir gecikme alınmıștır (Ek tablo 1)

Testlerdeki olasılık değerleri anlamlı çıkması durumunda $\mathrm{HO}$ : Granger nedeni değildir hipotezi reddedilir ve birinci seri, ikinci serinin Granger nedeni olarak kabul edilir. Tablo 8'de \%5 olasılık anlamlılık düzeyinin alında olan değișkenler arası Granger nedensellikler göste- 
rilmektedir. Detaylı istatistiki sonuçlar ise ek tablo 2'de bulunmaktadır. Aylık pozisyon verilerinin ortalamalarının aylık getiri üzerine Granger nedensellik olduğuna dair anlamlı sonuçlar çıkmamıștır. Günlük sık frekanslı verilerden olușan vadeli fiyatların, aylık frekanstaki pozisyon etkilerine karșı olan tepkilerini hızlı bir șekilde düzeltip günler içinde etkinin kaybolması, Granger nedensellik analizlerinde istatistiki anlamlı sonuçlara ulașılamamasının bir sebebi olabilir, bu ise ayrı bir araștırma konusudur. Sonuç olarak, aylık getirinin ithalat, Çin stok/kullanım oranı ve Çin dıșı tüketim verilerinin Granger nedeni olduğu sonuçları görülmüștür.

Tablo 8. Getirilerin Aylık Reel Dinamik Serileri ile Granger Nedensellik Yönleri

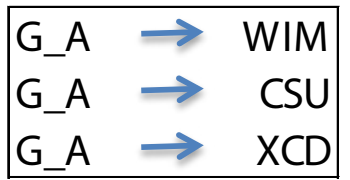

*Sonuçlar \%5 olasılık değerinde anlamlı sonuçlar vermiștir, detaylı tablo EK10'dadır.

\section{Sonuç}

Son yıllarda küreselleșmenin ilerlemesi ve teknolojinin gelișmesi ile birlikte vadeli emtia piyasalarına olan ilgi hem korumacılar hem de spekülatörler tarafından artmıștır. Masters, vadeli piyasalardaki artan hacmi ve 2008 krizinde olușan fiyatları ișaret ederek, beklenmedik spekülatif alımların baskısı vadeli emtia fiyatlarında balona sebebiyet vermekte ve bunun da spot fiyatları artırmasına neden olmakta tezini savunmuștur (Masters \& White, 2008). Literatürde, spekülatörlerin emtia piyasalarındaki aktivitelerinin genel olarak istikrarı bozucu olmadığı yapılan araștırmalarla anlașılsa da (Irwin \& Sanders, 2012a) emtia ve dönem özelinde spekülatif baskıların fiyat üzerindeki etkileri de görülmüștür. Dönem ve emtia özelinde spekülatif baskıların fiyat üzerinde kısıtı etkileri olduğunu gösteren çalıșmalardan örnek verilirse, Daley (2013) petrol; Manera ve diğerleri (2013) soya ve mısır; Guilleminot ve diğerleri (2013) ve Apperson (2017) pamuk emtiasında spekülatif hareketlerin fiyat ile ilișkisini ortaya koymușlardır. Arz-talep teorisine göre, reel miktarsal talebin artması fiyatları arttıracağı, reel miktarsal arzın artması fiyatları azaltacağı ve emtiaya özel olarak stokların artması sebebiyle fiyatları azaltacağı yönündedir. Konuyla ilgili geçmiș çalıșmalara bakıldığında; Macdonald (2009), ABD arz ve talep dinamiklerinin ABD arazi pamuk 
fiyatını etkilediği; Chua ve Tomek (2010), mısır emtiasında beklenen üretim vadeli fiyatları düșürdüğünü; James (2015), 2002 ile 2008 arasında petrol ve bakır emtiasında talebin fiyatı etkilediği; Janzen (2013) pamuk emtiasında stokların fiyatları etkilediğini söylemișlerdir.

Vadeli pamuk emtiası getirisinin spekülatörlerin vadeli kontrat "pozisyonlarının" ve "reel dinamik" verilerinin -üretim, tüketim, stok- getiri ile etkileșimde olabileceği düșünülmektedir. Bu iki olgunun getiri üzerindeki etkisi aynı modelde incelenmiștir. Piyasa katılımcılarının pozisyonlarının ve reel dinamik değișkenlerinin hem kendi aralarında hem de getiri üzerindeki etkileșimleri karșılaștırmalı olarak tek bir model üzerinde çalıșılmıștır. 2009-2018 aylık getiri verileri üzerinde kurulan EKK modelinde ARCH etkisi olduğu tespit edilmiștir ve sonrasında koșulları sağlayan $\operatorname{EGARCH}(1,1)$ modeli olușturulmuștur. Model üzerinde, korumacı olmayanlar net uzun pozisyonlar (KXN_AY), spekülatörler kısa pozisyonlar (SPK_AY), Çin dıșı ülkeler stok/kullanım oranı (XCR) ve Çin stok/kullanım oranı (CSU) istatistiki anlamlı sonuçlar vermiștir. Pozisyon verilerinde, aylık spekülatif uzun net pozisyon değișimlerinin aylık getiri ile pozitif, spekülatif kısa pozisyon değișimlerinin aylık getiri ile negatif ilișkili olduğu görülmüștür. Her iki stok/kullanım oranlarının getiri ile negatif ilișkide olduğu görülmüștür. Çin dıșı ülkelerin stok kullanım oranlarının Çin stok kullanım oranına göre getiri üzerinde daha fazla etkisi vardır. Pozisyon ve reel dinamik verilerinin getirinin üzerindeki etkilerini karșılaștırdığımızda ise stok/kullanım verilerinin, spekülatif pozisyonlarının değișimlerine göre getiri üzerinde daha büyük etkiye sahip olduğu anlașılmıștır. Getirinin varyansının kendi geçmiș değerlerinden ve hata terimi karelerinden etkilendiği görülmüștür. Ayrıca Granger nedensellik analizine göre getirinin ithalat, Çin stok/kullanım oranı ve Çin dıșı tüketim verilerinin Granger nedeni olduğu görülmüștür. Fakat tersi olan pozisyon ve reel dinamik verileri getirinin Granger nedeni çıkmamıștır. WASDE raporları frekansına uyum sağlama adına günlük frekanslı verilerden olușan vadeli fiyatlara ve haftalık frekanstaki pozisyon verilerine aylık çevrim yapılmıștır. Aylık frekanslı veriler, Granger nedensellik analizlerinde istatistiki anlamlı sonuçlara ulașılamamasının bir sebebi olabilir, bu ise ayrı bir araștırma konusudur.

Vadeli pamuk emtiası, az sayıda çalıșmaya konu olmuștur ve incelenen çalıșmalarda genel bulguların dıșında sonuçlar görülmüștür. Genel literatüre göre dünyada bașı çeken petrol, faiz, fx gibi vadeli ișlemlerin getirileri ve fiyatları üzerine spekülatif pozisyonların belirli etkileri olmadığıdır. Fakat emtia ve dönem özeline göre bulgular deği- 
șiklik göstermektedir. Pamuk emtiasında getiri ve pozisyon etkileșiminin bulgularının çıkması, piyasanın daha sığ olmasından kaynaklı olabilir. Bu konu, ileride yapılacak ayrı bir çalıșma ile araștırmaya açıktır. Ayrıca șu an Türkiye'de dar olan vadeli emtia piyasalarının gelișmesini beklemeden, piyasadaki açık pozisyon verileri toplanarak ileride olușabilecek spekülatif atakların önüne geçebilecek bir denetleme sisteminin kurulması faydalı olacaktır. Son olarak, vadeli pamuk emtiası piyasalarında ișlem yapacak korumacı ve yatırımcıların, bekledikleri ya da bütçeledikleri fiyat üzerinden vadeli ișlem piyasalarında fiyat ararken, çalıșmada ele alınan spekülatör katılımcılarının pozisyonlarının ve reel dinamik unsurlarının getiri üzerindeki sonuçlarına göre önem sırasında izlenmesi ve piyasa katılımcılarının kendi fiyat belirleme analizlerine bu unsurları dahil etmeleri önerilmiștir. 


\section{KAYNAKÇA}

Apperson, G. P. (2017). Agricultural Commodity Futures Price Volatility: A Market Regulatory Policy.

Brooks, C. (2008). Introductory Econemetrics for Finance. Cambridge.

Brunetti, C., Büyükșahin, B., \& Harris, J. H. (2011). Speculators, Prices and Market Volatility.

CFTC. (2018). Agency Financial Report.

CFTC. (2018a). Commitments of Traders Report.

Chua, H. W., \& Tomek, W. G. (2010). On the Relationship of Expected Supply and Demand to Futures Prices. Proceedings of the NCCC-134 Conference on Applied Commodity Price Analysis, Forecasting, and Market Risk Management. St. Louis.

Clarke, R. G., Silva, H. d., \& Thorley, S. (2013). Fundamentals of Futures and Options. CFA Institute.

Daley, C. E. (2013). Investigation Of Crude Oil Speculation And Subsequent Economic Implications.

Gökbulut, R. İ., \& Pekkaya, M. (2014). Estimating and Forecasting Volatility of Financial Markets Using Asymmetric GARCH Models: An Application on Turkish Financial Markets. International Journal of Economics and Finance; Vol. 6, No. 4;.

Granger, C. (1969). Investigating causal relations by econometric models and crossspectral methods. Econometrica, 37, 424-438.

Guilleminot, B., Ohana, J.J., \& Ohana, S. (2013). The Interaction of Speculators and Index Investors in a Agricultural Derivatives Markets.

Hair, J. F., Anderson, R. E., Tatham, R. L., \& Black, W. C. (1995). Multivariate Data Analysis, 3. baskı. New York: Macmillan Publishing Company.

Hull, J. (2012). Options, Futures and Other Derivatives. Peardon.

Irwin, S. H., \& Sanders, D. R. (2012a). Testing the Masters Hypothesis in Commodity Futures Markets. Energy Economics, 34, 256-269.

Irwin, S. H., \& Sanders, D. R. (2012b). Financialization and Structural Change in Commodity Futures Markets. Journal of Agricultural and Applied Economics, 44, 371396.

Jacks, D. S., \& Stuermer, M. (2016). What Drives Commodity Price Booms and Busts? Federal Reserve Bank of Dallas Research Department.

James, A. T. (2015). An Investigation of Commodity Spot and Futures Prices.

Janzen, J. P. (2013). Three Essays on Price Discovery in the Cotton Futures Market.

Keynes, J. (1930). A Treatise on Money. Harcourt.

Lehecka, G. V. (2013). Hedging and Speculative Pressures: An Investigation of the Relationships among Trading Positions and Prices in Commodity Futures Markets. 
Macdonald, S. (2009). U.S. Cotton prices and the world cotton market: Forecasting and structural change. USDA Economic Research Report Number 80.

Manera, M., Nicolini, M., \& Vignati, I. (2013). Futures price volatility in commodities markets: The role of short term vs long term speculation. USAEE Working Paper No. $13,128$.

Masters, M. W., \& White, A. K. (2008). How Institutional Investors Are Driving Up Food And Energy Prices (Special Report).

Nelson, D. (1991). Conditional Heteroskedasticity in Asset Returns: A New Approach. Econometrica 59(2), 347-70.

Özaydın, O. (2019). Vadeli Pamuk Emtiası Getirilerinin Piyasa Oyuncuları ve Reel Piyasa Dinamikleri ile Etkileșimi. İstanbul.

Özden, Ü. H. (2008). IMKB Bileșik 100 Endeksi Getiri Volatilitesinin Analizi. İstanbul Ticaret Üniversitesi Sosyal Bilimler Dergisi, 339-350.

Sevütekin, M., \& Nargeleçekenler, M. (2010). Ekonometrik Zaman Serileri Analizi. Ankara: Nobel. 


\section{EKLER}

Ek Tablo 1. Aylık Pozisyonlar ve Reel Beklentilerin Getiri ile Granger Nedensellik Analizi İçin Bulunan Gecikme Sayıları Test Kriterleri

\begin{tabular}{c|ccc|}
\cline { 2 - 4 } Gec. & \multicolumn{3}{|c|}{ G_A - KXN_AY } \\
\cline { 2 - 4 } & AIC & SC & HQ \\
0 & -3.070715 & -3.02217 & -3.051019 \\
$1^{*}$ & -3.207448 & $-3.061814^{*}$ & $-3.148359^{*}$ \\
2 & $-3.220713^{*}$ & -2.97799 & -3.122233 \\
3 & -3.159875 & -2.820063 & -3.022002 \\
4 & -3.111076 & -2.674174 & -2.933811 \\
5 & -3.102196 & -2.568205 & -2.885539 \\
6 & -3.082479 & -2.451399 & -2.82643 \\
7 & -3.062503 & -2.334334 & -2.767062 \\
8 & -3.047292 & -2.222033 & -2.712458 \\
\hline
\end{tabular}

\begin{tabular}{c|ccc|}
\cline { 2 - 4 } Gec. & \multicolumn{3}{|c|}{ G_A - SPK_AY } \\
\cline { 2 - 4 } & AIC & SC & HQ \\
0 & -2.089089 & -2.040545 & -2.069393 \\
$1^{*}$ & $-2.192601^{*}$ & $-2.046968^{*}$ & $-2.133513^{*}$ \\
2 & -2.180208 & -1.937485 & -2.081727 \\
3 & -2.118945 & -1.779133 & -1.981072 \\
4 & -2.085932 & -1.64903 & -1.908667 \\
5 & -2.078855 & -1.544864 & -1.862197 \\
6 & -2.047256 & -1.416176 & -1.791207 \\
7 & -1.982813 & -1.254643 & -1.687371 \\
8 & -1.977904 & -1.152645 & -1.64307 \\
\hline
\end{tabular}

\begin{tabular}{c|ccc|}
\cline { 2 - 4 } Gec. & \multicolumn{3}{|c|}{ G_A-WIM } \\
\cline { 2 - 4 } 0 & AIC & SC & HQ \\
0 & -7.214583 & $-7.166038^{*}$ & -7.194887 \\
$1^{*}$ & $-7.309572^{*}$ & -7.163938 & $-7.250484^{*}$ \\
2 & -7.290381 & -7.047657 & -7.1919 \\
3 & -7.248444 & -6.908632 & -7.110572 \\
4 & -7.216119 & -6.779217 & -7.038854 \\
5 & -7.186651 & -6.65266 & -6.969994 \\
6 & -7.181588 & -6.550508 & -6.925539 \\
7 & -7.111493 & -6.383323 & -6.816051 \\
8 & -7.073586 & -6.248327 & -6.738752 \\
\hline
\end{tabular}

\begin{tabular}{c|ccc|}
\cline { 2 - 4 } Gec. & \multicolumn{3}{|c|}{ G_A-CUS } \\
\cline { 2 - 4 } 0 & AIC & SC & HQ \\
0 & -7.917945 & -7.8694 & -7.898249 \\
$1^{*}$ & $-8.075968^{*}$ & $-7.930334^{*}$ & $-8.016880^{*}$ \\
2 & -8.053334 & -7.810611 & -7.954854 \\
3 & -8.008631 & -7.668818 & -7.870758 \\
4 & -7.975369 & -7.538467 & -7.798104 \\
5 & -7.951577 & -7.417586 & -7.73492 \\
6 & -7.936543 & -7.305463 & -7.680494 \\
7 & -7.872968 & -7.144798 & -7.577526 \\
8 & -7.829456 & -7.004197 & -7.494622 \\
\hline
\end{tabular}

\begin{tabular}{c|ccc|}
\cline { 2 - 4 } Gec. & \multicolumn{3}{|c|}{ G_A-CSU } \\
\cline { 2 - 4 } & AIC & SC & HQ \\
0 & -5.223817 & -5.175273 & -5.204121 \\
$1^{*}$ & $-5.462481^{*}$ & $-5.316847^{*}$ & $-5.403393^{*}$ \\
2 & -5.462348 & -5.219625 & -5.363867 \\
3 & -5.421648 & -5.081836 & -5.283776 \\
4 & -5.382199 & -4.945298 & -5.204935 \\
5 & -5.374823 & -4.840832 & -5.158166 \\
6 & -5.355123 & -4.724043 & -5.099074 \\
7 & -5.327147 & -4.598978 & -5.031706 \\
8 & -5.334674 & -4.509415 & -4.99984 \\
\hline
\end{tabular}

\begin{tabular}{c|ccc|}
\cline { 2 - 4 } Gec. & \multicolumn{3}{|c|}{ G_A - XCR } \\
\cline { 2 - 4 } 0 & AIC & SC & HQ \\
0 & -6.362457 & -6.313912 & -6.342761 \\
$1^{*}$ & -6.481071 & $-6.335437^{*}$ & $-6.421983^{*}$ \\
2 & $-6.483103^{*}$ & -6.240379 & -6.384622 \\
3 & -6.434384 & -6.094572 & -6.296512 \\
4 & -6.37325 & -5.936348 & -6.195985 \\
5 & -6.359426 & -5.825435 & -6.142769 \\
6 & -6.323545 & -5.692465 & -6.067496 \\
7 & -6.316717 & -5.588548 & -6.021276 \\
8 & -6.302486 & -5.477227 & -5.967652 \\
\hline
\end{tabular}

\begin{tabular}{c|ccc|}
\cline { 2 - 4 } Gec. & \multicolumn{3}{|c|}{ G_A - XCD } \\
\cline { 2 - 4 } & AIC & SC & HQ \\
0 & -8.847707 & -8.799162 & -8.82801 \\
$1^{*}$ & -8.947615 & $-8.801981^{*}$ & $-8.888527^{*}$ \\
2 & $-8.974797^{*}$ & -8.732074 & -8.876316 \\
3 & -8.93898 & -8.599167 & -8.801107 \\
4 & -8.896793 & -8.459892 & -8.719529 \\
5 & -8.872323 & -8.338332 & -8.655665 \\
6 & -8.840668 & -8.209588 & -8.584619 \\
7 & -8.77775 & -8.049581 & -8.482309 \\
8 & -8.771953 & -7.946694 & -8.437119 \\
\hline
\end{tabular}




\section{Ek Tablo 2. Getiri ile Aylık Pozisyon ve Reel Dinamik Değișkenleri Arasındaki} Granger Nedensellik Test İstatistikleri

\begin{tabular}{|lccc|}
\hline & F-isstatistik & Olasıllık & Granger Nedenselik Yönü \\
KXN_AY Granger neden değildir, G_A & 0.6178 & 0.4335 & Granger nedeni değildir \\
G_A Granger neden değildir, KXN_AY & 0.0000 & 0.9967 & Granger nedeni değildir \\
\hline & & & Granger Nedenselik Yönü \\
\hline & F-İstatistik & Olasılık & Granger nedeni değildir \\
SPK_AY Granger neden değildir, G_A & 0.3979 & 0.5294 & Granger nedeni değildir \\
\hline
\end{tabular}

\begin{tabular}{|lccc|}
\hline & F-isstatistik & Olasılık & Granger Nedenselik Yönü \\
WIM Granger neden değildir, G_A & 0.0020 & 0.9642 & Granger nedeni değildir \\
G_A Granger neden değildir, WIM & 4.5347 & 0.0353 & G_H, \%5 anlamlılık düzeyinde WIM'nin Granger nedenidir \\
\hline
\end{tabular}

\begin{tabular}{|lccc|}
\hline & F-i̇statistik & Olasılık & Granger Nedenselik Yönü \\
CUS Granger neden değildir, G_A & 0.1708 & 0.6801 & Granger nedeni değildir \\
G_A Granger neden değildir, CUS & 0.0430 & 0.8362 & Granger nedeni değildir \\
\hline
\end{tabular}

\begin{tabular}{|lccc|}
\hline & F-ìstatistik & Olasılık & Granger Nedenselik Yönü \\
CSU Granger neden değildir, G_A & 0.3449 & 0.5582 & Granger nedeni değildir \\
G_A Granger neden değildir, CSU & 5.4834 & 0.0209 & G_A, \%5 anlamlılık düzeyinde CSU'nun Granger nedenidir \\
\hline
\end{tabular}

\begin{tabular}{|lccc|}
\hline XCR Granger neden değildir, G_A & F-isstatistik & Olasıllık & Granger Nedenselik Yönü \\
G_A Granger neden değildir, XCR & 1.2617 & 0.2637 & Granger nedeni değildir \\
& & & Granger nedeni değildir \\
\hline & F-isstatistik & Olasılık & Granger Nedenselik Yönü \\
XCD Granger neden değildir, G_A & 1.22308 & 0.2710 & Granger nedeni değildir \\
G_A Granger neden değildir, XCD & 4.91424 & 0.0286 & G_A, \%5 anlamlılık düzeyinde XCD'nın Granger nedenidir \\
\hline
\end{tabular}


